\title{
The Distribution and Sources of Heavy Metals in Fine Particulate Matter in an Indoor Micro Environment of a Residential Area of Lagos state, Nigeria
}

\author{
Oyibo, F.O. ${ }^{1 *}$, Chiedu, I.E. ${ }^{2}$, Obasuyi A.C. ${ }^{3}$, Edomwonyi O.L. ${ }^{1}$,Akanji, A.A ${ }^{1}$ \\ ${ }^{I}$ Environmental Analytical Research Laboratory, Department of Chemistry, University of Benin, Benin City, \\ Edo State \\ ${ }^{2}$ Department of Production, Analytical and Laboratory Management, Federal Institute of Industrial Research \\ Oshodi, Lagos State, Nigeria \\ ${ }^{3}$ Institute of Health Technology, University of Benin Teaching Hospital, Benin City Edo State
}

*Corresponding Author: Oyibo, F.O, Environmental Analytical Research Laboratory, Department of Chemistry, University of Benin, Benin City, Edo State

\begin{abstract}
Clean air is very vital for the continual existence of man and all other higher forms of life on Earth. Unfortunately, anthropogenic activities such as industrialization and urbanization have significantly impaired the atmospheric air composition. Particulate matter (PM) comprises of different particles but, trace metals and trace organic compounds are the major components of PM that raise the most health concern. In general, PM and its content have enormous economic and social negative adverse impacts on man and his environment. This study aims at collecting base-line information of total suspended particulates (TSP) in an indoor micro environment in a residential area of Lagos state which might be necessary to develop existing air quality criteria and air quality standards. Samples were collected from July, 2016 to June, 2017 using a portable high volume sampler $(\mathrm{Hi}-\mathrm{Q} C \mathrm{CF}$ - 901). The weight of samples collected were determined gravimetrically and thereafter, analyzed for elemental concentrations using Atomic Absorption Spectroscopic $(A A S)$ method. The elemental concentrations were subjected to Principal Component Analysis (PCA) for source identification and Analysis of Variance (ANOVA) for temporal variation. The results show a high base-line concentrations range of 833.33-1944.45 $\mu \mathrm{gm}$-3and 1111.11-2777.78 $\mu \mathrm{gm}-3$ during the wet and dry season of the sampling period respectively. The result of the PCA identified road dust, vehicular emission and waste burning as the predominant sources of emission to the environment. The ANOVA result shows that there was no significant temporal variation in most of the analysed metals. Conclusively, results obtained show that, pollutants concentration in most of the sites were higher than safe limits proposed by regulatory bodies.
\end{abstract}

Keywords: Indoor, Air pollution, Heavy metals, Source identification, Temporal variation

\section{INTRODUCTION}

Air pollution is a now a major issue both in developing and developed countries globally as a result of its adverse impacts on human health, visibility degradation and global climate change. $[1,2,3$, 4].Air pollution can be grouped into two categories: outdoor air pollution (OAP) and indoor air pollution (IAP) [5]. The indoor air pollution refers to air pollution in the indoor micro environment and can occur from a wide variety of sources depending on the type of activities and processes taking place [6]. Another source of indoor air pollution is the outdoor air. The most important environment that relates to human health is the indoor environment since, people spend as much as $90 \%$ of their time indoors [7]. Consequently, indoor air quality (IAQ) has gained great attention in recent years as it is considered one of the top five environmental risks to the public's health. The Environmental Protection Agency (EPA) defines IAQ as "the air quality within and around buildings and structures, especially as it relates to the health and comfort of building occupants" [8]. Air quality testing in homes across the United States estimated that $96 \%$ of homes had at least one problem with IAQ; approximately $85 \%$ had elevated concentrations of particulates and bioaerosols and approximately $71 \%$ were filled with odors and potentially harmful chemicals and gases [9]. 
Studies have revealed that, air pollutants are about two to five times higher indoors compared to outdoors and can even be 100 times higher than outdoor levels [10, 11]. It can even be worse in overcrowded, poorly ventilated, old homes and poor prevailing metrological factors [12]. Hence, indoor pollution is presumed to be more harmful than outdoor pollution. Global data shows that, IAP is far more lethal than OAP. Indoor air contaminants can cause acute or chronic health problems [13, 14,15]. Previous research has associated acute health problems such as headache, nausea and respiratory infections to the quality of the indoor air [16]. It has been estimated that about half a million women and children die yearly from indoor air pollution in India [17]. According to World Health Organization (WHO), indoor pollution resulting from cooking stove, caused the death of 1.6 million people in 2006; of the 1.6 million deaths, 396,000 deaths occurred in sub - Sahara Africa with highest incidents in Nigeria [18. 19]. Another WHO report posited that 78\% of African population use charcoal and firewood burning (biomass fuel) for cooking and that, a third of infant deaths associated with IAP occurred in Africa [20]. Also, a recent comparative risk study by the organizationshow that, $28 \%$ of the overall disease and deaths is caused by indoor air particulate matter in developing countries.

Knowing and controlling common indoor air pollutants can help reduce the risk of indoor health concerns [8]. Also, eliminating the source of the pollution amongst others can help to control IAQ [21]. This study focuses on base data collection of TSP, elemental content determination and source identification of pollutants in the indoor micro environment ofa residential area in Lagos State, Nigeria.

\section{MATERIALS AND MethodS}

\subsection{Sampling Site Description}

The TSPsamples from which the analyzed metals in this study were extracted and quantified, were collected from three locations in Akoka, a residential area within the Lagos metropolis.Prominent in this area are: residential homes, banks, small-scale businesses, tertiary institutions, artisans and more to be mentioned. Man-made activities in the above mentionedplaces are capable of releasing pollutants into the atmosphere.

Site 1 is a food vendor that uses charcoal as the cooking fuel and with alot of cooking activities. Site 2 is a home located along a busy street around a busy bus-stop. It uses kerosene as the cooking fuel. Site 3 is a restaurant situated between two banks. Also, situated close by, is a campus shuttle, business centres and other man-made activities capable of generating pollutants. This site uses liquefied petroleum gas (LPG) as a cooking fuel. The sampling sites are as shown on figure 1.

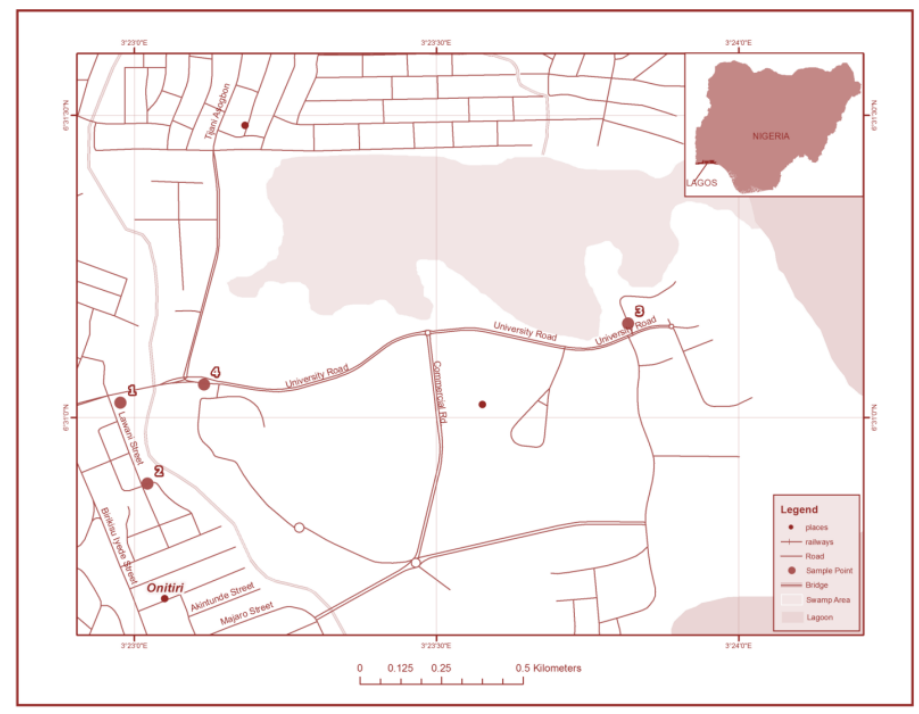

Figure1. Map of Akoka showing the sampling sites

\subsection{Sample Collection}

TSP sample was collected on a pre-weighed filter using a portable gravimetric air sampler (Hi-Q CF 901) at a flow rate of $2.5 \mathrm{~L} /$ minfor 8 hours between 8:00 am and 4: pm and at a height of about $1.6 \mathrm{~m}$ 
The Distribution and Sources of Heavy Metals in Fine Particulate Matter in an Indoor Micro Environment of a Residential Area of Lagos state, Nigeria

on each sampling occasion. Sampling was carried out from July 2016 to June 2017; this period covers the wet and dry season of the sampling period. For each sampling, the filter and cassette was humidity conditioned (equilibrated) in a charged desiccator for 24 hours and weighed before and after sampling. After sampling, the loaded filter was stored in sealed polythene bag and taken to laboratory for sample preparation and elemental analysis by Atomic Absorption Spectroscopy (AAS).

\subsection{Sample Preparation}

The loaded filter paper was carefully placed inside a $100 \mathrm{ml}$ beaker. $10 \mathrm{ml}$ of nitricacidwas added and heated at $150^{\circ} \mathrm{C}$ in a fume cupboard. The sample was intermittently spiked with $5 \mathrm{ml}$ perchloric acid after an hour and was heated for three hours until a clear solution was observed. The digest was cooled, filtered into $100 \mathrm{ml}$ standard volumetric flask and diluted with distilled water to the $\mathrm{ml}$ mark in the $100 \mathrm{ml}$ volumetric flask. A blank sample was prepared in the same manner. Elemental analysis was then carried out on the final digest and the blank using Perkin Elmer A Analyst 400 atomic absorption spectrophotometer. The blank concentration was duly subtracted from the obtained concentration. The alkali and alkali-earth metals were analyzed using Sherwood Model 410 Flame Photometer.

\subsection{Principal Component Analysis (PCA)}

Multivariate factor analysis was used to identify a probable number of contributing source factors to metals emission at the sampling sites [22, 23]. The elemental concentrations of the TSP samples were subjected to PCA with varimax rotation and only factors with eigen values $\geq 1$ were considered significant and retained [24].

\subsection{Analysis of Variance (ANOVA)}

In order to determine the seasonal variation of the elemental concentrations in the various sampling sites, the concentrations of the analyzed metals for the two seasons were subjected to ANOVA.

\section{RESULTS AND DISCUSSION}

The mass concentrations obtained in the indoor micro environments during the study period is depicted in Table 1.

Table1. Mass Concentration of Total Suspended Particulates (TSP) in $\mu \mathrm{g} / \mathrm{m}^{3}$

\begin{tabular}{|c|c|c|c|c|c|c|}
\hline & \multicolumn{3}{|c|}{ Wet Season } & \multicolumn{3}{c|}{ Dry season } \\
\cline { 2 - 7 } & Minimum & Maximum & Mean \pm S.D & Minimum & Maximum & Mean \pm S.D \\
\hline $\begin{array}{c}\text { Site } \\
1\end{array}$ & 833.33 & 2500.00 & $1945.44 \pm 96.23$ & 2500.00 & 3333.33 & $2777.78 \pm 48.11$ \\
\hline $\begin{array}{c}\text { Site } \\
2\end{array}$ & 833.33 & 1666.67 & $1388.89 \pm 48.11$ & 416.67 & 2500.00 & $1527.78 \pm 120.28$ \\
\hline $\begin{array}{c}\text { Site } \\
3\end{array}$ & 416.67 & 1666.67 & $833.34 \pm 72.17$ & 833.33 & 1666.67 & $1111.11 \pm 48.11$ \\
\hline \multicolumn{3}{|c|}{ Gross mean mass concentration 1389.22} & \multicolumn{3}{|c|}{ Gross mean mass concentration 1805.56} \\
\hline
\end{tabular}

The mean mass concentration obtained in the indoor micro environment in the study area ranged from 833.34 to $1945.44 \mu_{\mathrm{gm}^{-3}}$ with a gross mean mass concentration of $1389.22 \mu \mathrm{gm}^{-3}$ during the wet season and 1111.11 to $2777.78 \mu \mathrm{gm}^{-3}$ with a gross mean mass concentration of $1805.56 \mu \mathrm{gm}^{-3}$ during the dry season of the sampling period. The highest and lowest mean concentration was obtained in site 1 and site 3 respectivelyin both seasons (Table 3.1a). The mean concentration in all the sites clearly violate the statutory limit of $230 \mu^{-3}$ stipulated by the World Health Organization [25] and 150-250 $\mu \mathrm{gm}^{-3}$ by Federal Ministry of Health [26]. These high concentrations obtained is a signature of high human activities and the variation in concentrations, is mostly likely connected with variations in human activities in the various sites.

Table2. Comparison of Indoor-Outdoor Total Suspended Particulate Matter Results $\left(\mu_{\mathrm{gm}}{ }^{-3}\right)$ of this Study with others

\begin{tabular}{|c|c|c|c|}
\hline S/N & Site/Location & Indoor concentration & References \\
\hline 1 & Urban/Lagos & $833.33-2777.78$ & Current Study \\
2 & Urban/Riyadh & $62-473$ & {$[27]$} \\
3 & Urban/Kosice & $59.03-114.58$ & {$[28]$} \\
\hline
\end{tabular}

International Journal of Advanced Research in Chemical Science 
The Distribution and Sources of Heavy Metals in Fine Particulate Matter in an Indoor Micro Environment of a Residential Area of Lagos state, Nigeria

\begin{tabular}{|c|c|c|c|}
\hline \multicolumn{2}{|c|}{} & \\
\hline 4 & Urban/Benin City & $243.05-451.39$ & {$[4]$} \\
6 & Rural/Iyowa & $425.92-1444.00$ & {$[29]$} \\
7 & Rural/China & 2000 & {$[30]$} \\
8 & Urban/Saudi Arabia & 1845.90 & {$[31]$} \\
9 & Urban/Zagreb & 90.00 & {$[32]$} \\
10 & Urban/Bomby & 118.00 & {$[32]$} \\
& Urban/Toronto & 68.00 & {$[32]$} \\
& WHO & 230 & {$[25]$} \\
\hline
\end{tabular}

The concentrations of TSP recorded in this study and in some other studies (Table 3 ) are quite above the limits stipulated by regulatory bodies $[25,26]$ and this is a signature of anthropogenic contributions that requires air regulatory enforcement

\subsection{Elemental Concentration}

One of the most toxic constituents of atmospheric particulates is heavy metals (HMs) and so, environmental contamination and exposure to HMs is a serious growing problem across the globe as their occurrence in air contributes to substantial health effects [33]. Unfortunately, exposure cannot be totally averted in today's society as the society depends on them for proper functioning. As a matter of fact, human exposure to HMs has risen drastically in the past 5 decades owning to an exponential increase in their uses in industrial and agricultural processes. Several occupations involve exposure to HMs daily; over 50 professions entail exposure to $\mathrm{Hg}$ alone [34].

The mean elemental concentrations of HMs analysed in the indoor micro environments during the wet and dry seasons of the sampling period are presented in Table 3and Table 4 respectively.

Table3. Mean Elemental Concentration $\left(\mu \mathrm{gm}^{-3}\right)$ of Total Suspended Particulate Matter during the Wet Season

\begin{tabular}{|c|c|c|c|}
\hline \multirow{2}{*}{ Elements } & Site 1 & Site 2 & Site 3 \\
\cline { 2 - 4 } & Mean \pm S.D & Mean \pm S.D & Mean \pm S.D \\
\hline $\mathrm{Pb}$ & $1.06 \pm 0.30$ & $1.14 \pm 0.23$ & $0.27 \pm 0.19$ \\
\hline $\mathrm{Cd}$ & $0.09 \pm 0.13$ & $0.16 \pm 0.05$ & $0.84 \pm 0.07$ \\
\hline $\mathrm{Cu}$ & $0.05 \pm 0.01$ & $0.08 \pm 0.02$ & $0.05 \pm 0.06$ \\
\hline $\mathrm{Ni}$ & $1.17 \pm 0.22$ & $1.32 \pm 0.35$ & $1.27 \pm 0.13$ \\
\hline $\mathrm{Fe}$ & $1.78 \pm 0.18$ & $2.09 \pm 0.28$ & $2.01 \pm 0.26$ \\
\hline
\end{tabular}

Table4. Mean Elemental Concentration $\left(\mu \mathrm{gm}^{-3}\right)$ of Total Suspended Particulate Matter during the Dry Season

\begin{tabular}{|c|c|c|c|}
\hline \multirow{2}{*}{ Elements } & Site 1 & Site 2 & Site 3 \\
\cline { 2 - 4 } & Mean \pm S.D & Mean \pm S.D & Mean \pm S.D \\
\hline $\mathrm{Pb}$ & $1.12 \pm 0.26$ & $1.26 \pm 0.07$ & $0.46 \pm 0.33$ \\
\hline $\mathrm{Cd}$ & $0.16 \pm 0.16$ & $0.38 \pm 0.19$ & $0.80 \pm 0.13$ \\
\hline $\mathrm{Cu}$ & $0.09 \pm 0.11$ & $0.10 \pm 0.02$ & $1.29 \pm 0.83$ \\
\hline $\mathrm{Ni}$ & $1.21 \pm 0.44$ & $1.56 \pm 0.35$ & $2.94 \pm 0.85$ \\
\hline $\mathrm{Fe}$ & $2.12 \pm 1.60$ & $2.29 \pm 0.65$ & 0.10 \\
\hline
\end{tabular}

Apart from $\mathrm{Cu}$, the mean concentration of the analyzed HMs in the various site were high. This can be attributed to vehicular emission, road dust, waste burning amongst others. The highest mean concentration of the HMs was observed in site 2. This is probably due to the location of the site, emission sources, dispersion conditions, occupants behavior amidst other factors. The highest level of $\mathrm{Pb}$ recorded in this site may not be unconnected with the age of the building and nature of paint used. It has been reported that emulsion and gloss types of paints currently manufacture and sold in Nigeria contained substantial levels of $\mathrm{Pb}$ [35]. Another reason for this elevated level of $\mathrm{Pb}$ detectedin this site and other sites in this study could beas a result of emissions from automobile exhaust and non exhaust since,all the sites are near possible automobile source of emission. Ambient lead concentrations typically peak near busy roadways. High traffic density increases the availability of $\mathrm{Pb}$ in the environment. This implies that, $\mathrm{Pb}$ is still being released or re- suspended by vehicle traffic because, it has long residence time[36].

The concentrations of the HMs measured during the wet season, were relatively lower than that measured during the dry season in the various sites. The low concentration of metals observed in the wet season might be attributed to metrological factors such as: (i)lower air temperature (ii) higher 
The Distribution and Sources of Heavy Metals in Fine Particulate Matter in an Indoor Micro Environment of a Residential Area of Lagos state, Nigeria

humidity, (ii)higher wind speed and(iii) increase in cloud covers and consequently, increase in the number of rainfall days experienced during the wet season. These factors help in minimizing the concentration of accumulated aerosol, trace metals and gaseous materials in air. At high humidity particulates are trapped in water molecules and later washed down via wet deposition. Also, the greater the wind speed, the greater the turbulence and the more rapid and complete the dispersion of contaminants in the air [37].

\subsection{Principal Component Analysis (PCA)}

The probable sources of metals emission in the study area were determined from the result of the PCA. During the wet season, two major factors were extracted which explained more than $76 \%$ of the cumulative variance. The elements in a particular factor loading, gives an indication of the possible source of emission. Factor 1 ( $\mathrm{PC} 1$ ) which comprises of $\mathrm{Cu}, \mathrm{Ni}, \mathrm{Fe}$ may be attributed to road dust source. Factor 2 ( $\mathrm{PC} 2$ ) loaded primarily by $\mathrm{Pb}, \mathrm{Cd}$ and $\mathrm{Cu}$. This factor may be attributed to waste burning. During the dry season, Factor 1 (PC1) loaded heavily on $\mathrm{Cd}, \mathrm{Cu}, \mathrm{Ni}$. This factor may be attributed to waste burning. Factor 2 (PC2) loaded primarily by $\mathrm{Cd}$ and Fe. This is most likely related to road dust. Factor 3 (PC3) which loaded primarily by $\mathrm{Pb}$ and Ni.may be attributed to vehicular emissions.

\subsubsection{Temporal variations of elemental concentration}

In order to determine the temporal variation of the elemental concentrations in the various sampling sites, the concentrations of the analyzed metals for the two seasons were subjected to ANOVA. The result of the ANOVAis as shown in Table 5.

Table5. Temporal variations of Elemental Concentrations

\begin{tabular}{|c|l|l|l|}
\hline & Wet season & Dry season & P \\
\hline Site 1 & & & 0.796 \\
\hline $\mathrm{Pb}$ & $1.06 \pm 0.30^{\mathrm{a}}$ & $1.12 \pm 0.26^{\mathrm{a}}$ & 0.524 \\
\hline $\mathrm{Cd}$ & $0.09 \pm 0.13^{\mathrm{a}}$ & $0.16 \pm 0.16^{\mathrm{a}}$ & 0.761 \\
\hline $\mathrm{Cu}$ & $0.05 \pm 0.01^{\mathrm{a}}$ & $0.09 \pm 0.11^{\mathrm{a}}$ & 0.918 \\
\hline $\mathrm{Ni}$ & $1.17 \pm 0.22^{\mathrm{a}}$ & $1.21 \pm 0.44^{\mathrm{a}}$ & 0.357 \\
\hline $\mathrm{Fe}$ & $1.78 \pm 0.18^{\mathrm{a}}$ & $2.12 \pm 0.11^{\mathrm{a}}$ & 0.039 \\
\hline $\mathrm{Site} \mathrm{2}$ & & & 0.121 \\
\hline $\mathrm{Pb}$ & $1.14 \pm 0.23^{\mathrm{a}}$ & $1.26 \pm 0.07^{\mathrm{b}}$ & 0.331 \\
\hline $\mathrm{Cd}$ & $0.16 \pm 0.05^{\mathrm{a}}$ & $0.38 \pm 0.19^{\mathrm{a}}$ & 0.391 \\
\hline $\mathrm{Cu}$ & $0.08 \pm 0.02^{\mathrm{a}}$ & $0.10 \pm 0.02^{\mathrm{a}}$ & 0.666 \\
\hline $\mathrm{Ni}$ & $1.32 \pm 0.35^{\mathrm{a}}$ & $1.56 \pm 0.35^{\mathrm{a}}$ & 0.109 \\
\hline $\mathrm{Fe}$ & $2.09 \pm 0.28^{\mathrm{a}}$ & $2.29 \pm 0.65^{\mathrm{a}}$ & 0.625 \\
\hline $\mathrm{Site} \mathrm{3}$ & & & 0.229 \\
\hline $\mathrm{Pb}$ & $0.27 \pm 0.19^{\mathrm{b}}$ & $0.46 \pm 0.33^{\mathrm{b}}$ & 0.977 \\
\hline $\mathrm{Cd}$ & $0.84 \pm 0.07^{\mathrm{b}}$ & $0.80 \pm 0.13^{\mathrm{b}}$ & 0.133 \\
\hline $\mathrm{Cu}$ & $0.05 \pm 0.06^{\mathrm{a}}$ & $0.13 \pm 0.10^{\mathrm{a}}$ & \\
\hline $\mathrm{Ni}$ & $1.27 \pm 0.13^{\mathrm{a}}$ & $1.29 \pm 0.83^{\mathrm{a}}$ & \\
\hline $\mathrm{Fe}$ & $2.01 \pm 0.26^{\mathrm{a}}$ & $2.94 \pm 0.85^{\mathrm{a}}$ & \\
\hline
\end{tabular}

Means with different superscript are statistically different

The result of ANOVA shows thatapart from $\mathrm{Pb}$ that showed significant variation in site $2(\mathrm{p}<0.05)$ during the dry season, there was no significant temporal variations in the concentrations of the analysedmetals in the various sites. The significant temporal variation observed in $\mathrm{Pb}$ concentration in site 1 ,is probably an indication that anthropogenic source(s) of emission of the metal during the dry season is more prevalent than the wet season. Other factors responsible for spatial and temporal variation which could also be responsible for the trend in this area include: emission strength, emission rate, emission conditions and atmospheric dispersion conditions [29].

\section{CONCLUSION}

A high base-line data of TSP and heavy metal content in the indoor micro environment of the study area was obtained during the study period. These values violate both the WHO and FMEV standard of

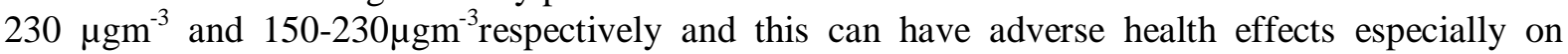
children, the elderly and those with pre-existing respiratory issues. Unless effectively controlled and 
The Distribution and Sources of Heavy Metals in Fine Particulate Matter in an Indoor Micro Environment of a Residential Area of Lagos state, Nigeria

managed, pollution which is undesirable but the necessary evil of all developments will continue to pose serious challenges to man and his environment most especially in developing countries.

The study identified vehicular emission, road dust and waste burning as the predominant sources of emission in these indoor micro environments. The study also showed that, the temporal variability in the measured data was not apparent except in $\mathrm{Pb}$ in site 2.

\section{REFERENCES}

[1] Laden F, Neas LM, Dockery DW, Schwartz J. 2000. Association of fine particulate matter from different sources with daily mortality in six U.S. cities. Environ Health Perspect 108: 941-947.

[2] Ramanathan, V., Crutzen, P. J., Lelieveld, J., Mitra, A.P., Althausen, D., Anderson, J., Andreae, M.O., Cantrell, W., Cass, G.R., Chung, C.E., Clarke, A.D., Coakley, J.A., Collins, W.D., Conant, W.C., Dulac, F., Heintzenberg, J., Heymsfield, A.J., Holben, B., Howell, S., Hudson, J., Jayaraman, A., Kiehl, J.T., Krishnamurti, T.N., Lubin, D., McFarquhar, G., Novakov, T., Ogren, J.A., Podgorny, I.A., Prather, K., Priestley, K., Prospero, J.M., Quinn, P.K., Rajeev, K., Rasch, P., Rupert, S., Sadourny, R., Satheesh, S.K., Shaw, G.E., Sheridan, P., Valero, F.P.J. (200). Indian Ocean Experiment: An Integrated Analysis of the Climate Forcing and Effects of the Great Indo-Asian Haze. J. Geophys. Res.106: 28371-28398.

[3] Watson, J.G. (2002). Visibility: Science and Regulation. Journal of the Air and Waste Management Association 52: 628-713. DOI: 10.1080/10473289.2002.10470813.

[4] W., Bai, Z., Liu, A., Chen, J., and Li, C. (2009). Characteristics of Major PM2.5Components during Winter in Tianjin, China. Aerosol Air Qual. Res.9: 105-119.

[5] United Nations Environment Programme (UNEP) (2001). A Handbook for Government Focal Points; Simplified Guide to the IPCC's " Climate Change 2001 Mitigation".

[6] Onabowale M.K. and Owoade O.K (2015).Assessment residential indoor outdoor airborne particulate matter in Ibadan, Southwestern Nigeria.Donnish.Journal of Physical Science.1(1):001- 007.

[7] Schweizer, R.D., Edwards, L., Bayer-Oglesby., Gauderman, W.J., Ilacqua, V., Jantunen, M.J., Lai, H.K., Nieuwenhuijsen, M., and Künzli N.(2007). Indoor time-microenvironment-activity patterns in seven regions of Europe. Journal of exposure science and environmental epidemiology. 17(2): 170-181.

[8] Environmental Protection Agency. (2016a, July 15). Introduction to Indoor Air Quality Retrieved July 20 , 2016, from EPA: https:/www.epa.gov/indoor-air-quality-iaq/introduction-indoor-air-quality.

[9] Crowder, J., Flick, C., Giliam, R., Klesch, L., Simpson, I., \&Smimova, Y. (2007). AirAdvice state of our indoor air.AirAdvice.

[10] Hess-Kosa, K. (2010). Indoor air quality: Sampling methodologies. CRC Press.

[11] Environmental Protection Agency (2016c, May 16). Volatile organic compounds' impact on indoor air quality. Retrieved January 20, 2017, from EPA: https:/www.epa.gov/indoor-air-quality-iaq/volatileorganic-compounds-impact-indoor-air-quality.

[12] Ediagbonya,T.F., Tobin,A.E. and Legemah, M. (2013). indoor and outdoor air quality In hospital environment.3(10):72-78.

[13] Bentayeb, M., Simoni, M., Norback, D., Baldacci, S., Maio, S., Viegi, G., \&Annesi-Maesano, I. (2013). Indoor air pollution and respiratory health in the elderly.Journal of Environmental Science and Health, Part A, 48(14), 1783-1789.

[14] Bentayeb, M., Norback, D., Bednarek, M., Bernard, A., Cai, G., Cerrai, S., \&Nasilowski, J. (2015). Indoor air quality, ventilation and respiratory health in elderly residents living in nursing homes in Europe.European Respiratory Journal, ERJ-00824.

[15] Maio, S., Sarno, G., Baldacci, S., Annesi-Maesano, I., \&Viegi, G. (2015). Air quality of nursing homes and its effect on the lung health of elderly residents.Expert Review of Respiratory Medicine, 6, 671-673.

[16] Curtis, L., Rea, W., Smith-Willis, P., Fenyves, E., \& Pan, Y. (2006). Adverse health effects of outdoor air pollutants. Environment International, 32(6), 815-830.

[17] Smith, K.R. (2000). Indoor air pollution implicated in alarming health problems In: Indoor air pollution energy and health for the indoor for the poor. Newsletter published by World Bank.

[18] WHO. (2006). "Fuel for Life: Household Energy and Health”. Available online: http://www.who.int/ indoor air/publications/fuelforlife.pdf (Accessed 1st December, 2016).

[19] Margulis, S., Paunio,M. and Acharya, A. (2006). “Addressing indoor air pollution in Africa: key to improving house hold health', Available online: http:// wwwunep.org/ urban_environment/ PDFs/ IAP Africa. pdf(Accessed 1st December, 2016). 
The Distribution and Sources of Heavy Metals in Fine Particulate Matter in an Indoor Micro Environment of a Residential Area of Lagos state, Nigeria

[20] WHO. (2007). "Indoor air pollution, health and burden of disease', Indoor air thematic briefing 2 , Geneva, Switzerland. Available at http://www.who.int/indoorair/info/briefing 2 pdf. (Accessed 1st December, 2016).

[21] New Hampshire Department of Environmental Services (2015). What can I do to help reduce air pollution? Available online @:http://www.des.nh.gov/organization/divisions/air/tsb/ams/aqmdp/share.htm.

[22] Ogulei, D., P. Hopke, L. Zhou, P. Paatero, S. Park, \& J. Ondov. (2005). Receptor Modeling for Multiple Time Resolved Species: The Baltimore supersite. Atmos. Environ. 39:3751-3762. doi:10.1016/j.atmosenv.2005.03.012.

[23] Wang,W.C., K.S. Chem, S.J. Chem, C.C. Lin, J.H. Tsai, C.H. Lai, \&S.K.Wang. (2008). Characteristics and Receptor Modeling of Atmospheric PM2.5 at Urban and Rural Sites in Pingtung, Taiwan. Aerosol Air Quality Res. 8,112-129.

[24] Huang, S.S., Tu, J., Liu, H.Y., Hua, M., Liao, Q.L., Feng, J.S., Weng, Z.H. \& Huang, G.M. (2009). Multivariate Analysis of Trace Element Concentrations in Atmospheric Deposition in the Yangtze River Delta, East China. Atmos. Environ 43, 5781-5790.

[25] WHO. (2005): Air Quality Global Update. A Report on a Working Group Meeting, Bonn, Germany, EUR/05/5046029.The World Health Organization.

[26] Federal Ministry of Environment.(2000). Guidelines and standards for Environmental pollution control in Nigeria. 67.

[27] Okuo, J.M. and Okolo, P.O. (2011). Levels of As, Pb, Cd And Fe in Suspended Particulate Matter (Spm) in Ambient Air of Artisan Workshops in Benin City, Nigeria. BayeroJournal of Pure and Applied Sciences. 4(2): $97-99$.

[28] Okuo, J.M. and Ndiokwere, C.I, (2005). Elemental characterization and source apportionment of air particulate matter in two contrastive industrial areas in Nigeria.Journal of Applied Sciences, 5: 1797-1801.

[29] Ukpebor, J. E., Ukpebor, E. E., Kadiri, V. I., Odiase, J. I., Okuo, J. M. and Ogbeifun, D. (2012). Atmospheric trace metal concentrations in suspended particulate matter (SPM) of a rural residential area in Southern Nigeria.Ife Journal of Science 14(1).

[30] Mumford, J.L., He, X.Z., Chapman, R.S, Cao, S.R, Harris, D.B, Li, X.M, Xian, Y.L, Jiang, W.Z, Xu, C.W, Chuang, J.C. (1987). Lung cancer and indoor air pollution in Xuan Wei, China.Science. 235(4785):217220.

[31] Mahmoud, F.E. and Mohamed, E. H. (2014). Indoor air quality levels in a University Hospital in the Eastern Province of Saudi Arabia. Journal Family Community Med.21(1):39-47. doi: 10.4103/22308229.128778.

[32] Fugas, M and De Koning, H.W. (1991).Comparative analysis of Indoor and Outdoor TSP Concentrations in Bombay, Toronto, and ZagrebJohn Wiley and sons limited.199-204.

[33] Wallenborn, J.G., Schladweiler, M.J., Richards, J.H and Kodavanti, U.P. (2009). Differential pulmonary and cardiac effects of pulmonary exposure to a panel of particulate matter- associated metals. Toxicology and Applied Pharmacology. 241: 71-82.

[34] Ezejiofor, T.I.N., Ezejiofor, A. N. Udebuani, A. C. Ezeji1, E. U..Ayalogbu, E. A., Azuwuike, C. O., Adjero, L. A. Ihejirika, C. E., Ujowundu, C. O., Nwaogu, C. O. andNgwogu, K. O. (2013). Environmental metals pollutants load of a densely populated and heavily industrialized commercial city of Aba, Nigeria. Journal of Toxicology and Environmental Health Sciences.5 (1): 1-11.

[35] Adebamowo, E.O., Agbede, O.A., Sridhar, M.K., and Adebamowo, C.A. (2006). An evaluation of lead levels in residential paints sold in Nigeria markets. Indoor built environment. 15: 551-554.

[36] Odukoya, O.O., Arowolo, T.A. and Bamgbose, O. (2000). Pb, $\mathrm{Zn}$ and Cu levels in tree barks as indicator of atmospheric pollution. Environ. Int. 26:11-16.

[37] Guttikunda, S.K. and Gurjar, B.R. (2012). Role of meteorology in seasonality of air pollution in megacity Delhi, India Environmental Monitoring and Assessment 184(5):3199-211. 011-2182-8.

Citation: Oyibo, F.O, et.al, "The Distribution and Sources of Heavy Metals in Fine Particulate Matter in an Indoor Micro Environment of a Residential Area of Lagos state, Nigeria”, International Journal of Advanced Research in Chemical Science, 7(4), pp. 1-7. DOI: http://dx.doi.org/10.20431/23490403.0704001

Copyright: () 2020 Authors, This is an open-access article distributed under the terms of the Creative Commons Attribution License, which permits unrestricted use, distribution, and reproduction in any medium, provided the original author and source are credited. 